\title{
Effect of Different Levels of Fat on the Chemical Composition and Sensory Characteristics of Sudanese Low-Fat Cheese during Storage
}

\author{
Elkhidier, I.E.A. ${ }^{(1)}$ and Hamid, O.I.A. ${ }^{2 *}$ \\ ${ }^{I}$ Department of Animal Production, Faculty of Agriculture and Natural Resources, Kassala University, Eastern \\ Sudan, New Halfa, Sudan. \\ ${ }^{2}$ Department of Dairy Science and Technology, College of Animal Production Science and Technology, Sudan \\ University of Science, and Technology, Khartoum North, Sudan
}

\begin{abstract}
The effect of different levels of fat on the chemical composition and sensory characteristics has been made from the following levels of milk fat: $3 \%, 2.5 \%$ and $2 \%$. The produced cheese was packed into sterile polyethylene bags (300 gram capacity) and stored at $4^{\circ} \mathrm{C}$ for three months. The chemical analysis was done at $0,30,60,90$ and 120 days. The results revealed that significant differences $(P<0.05)$ were found in protein, ash, total solid, $\mathrm{pH}$, volatile fatty acids and fat contents of the different cheese samples. Sensory characteristics and storage periodof the cheese samples showed significant variations $(P<0.05)$. The protein, total solids and ash increased throughout the storage period, the lowest values were $21.82 \pm 3.49 \%, 59.29 \pm 4.03 \%$ and $5.60 \pm 0.89 \%$ respectively obtained at day zero of the storage. The highest $\mathrm{pH}$ occurred at day zero of storage. It was also found that the volatile fatty acids(VFA) increased with the decrease levels of fat, the highest VFA $(2.62 \pm 0.50 \% 01 \mathrm{~N} \mathrm{ml} \mathrm{NaOH} / 100 \mathrm{gm})$ was observed in the cheese with $2.5 \%$ fat. The statistical analysis showed sensory characteristics of the cheese samples significant $(P<0.05)$ affected by the fat levels. The present study concluded that production of low-fat cheeses with valuable chemical composition and good quality for the health benefits of the consumers.
\end{abstract}

Keywords: fat level, chemical composition, Sudanese white cheese

\section{Introduction}

According to [1] cheese is a highly concentrated product which is rich in protein and minerals such as calcium and phosphorus and essential amino acids, therefore it is an important food in the diet. An excessive consumption of fat has been associated with an increased risk of health problems such as obesity, diabetes and cardiovascular diseases. Cheese is an excellent source of protein and minerals such as calcium and phosphorus, essential amino acids; therefore it is an important food for both young and old people [2].The protein concentration of milk varies according to the season, weather, feet type, stage of lactation, breed of lactating cows and health status of the animal (The incidence of Mastitis for instance;[3]. The variation has a major influence of the production of cheese [4].

Today, the properties and feature of gum Arabic have been widely explored and developed and it is being used in a wide range of industrial sectors such as textiles, ceramics, lithography, cosmetics, pharmaceuticals and food, regarding food industry. Gum Arabic is approved for use as food additive by the U.S. Food and Drug Administration and is on the list of substance "Generally recognized as saf" [5]. Gum Arabic is used as a stabilizer flavour fixative, a thickener, an adhesive and/or an emulsifier agent [6].

The acceptability of cheese depends on its appearance and sensory properties. Fat plays an important role in cheese of importing discontinuity to the protein matrix, so when fat is removed the cheese is composed of a homogenous dense protein network [7]. Since reduced-fat cheeses, especially fat-free cheeses are less acceptable to consumers than their full-fat counterparts due to their poor texture and dilute flavour, it is desirable to provide a non-fat soft cheese which emulates the organoleptic properties of soft cheese which contains substantial levels of milk fat. For this reason, fat replacer compounds are used to fully or partially replace fat in reduced-fat foods [8].

Many studies were focused on reducing calorie content of cheese and improving its textural and organoleptic properties [9]; [10] used different protein based fat replacers to obtained low-fat cheeses and their textural and sensory properties. [11] used modified tapioca starch and lecithin, as fat mimetics, to obtain reduced-fat and low-fat feta cheeses.In this study the main requirement for the component selection were as follows: it should be safe for the human body. The use of additive should no significantly complicate the product manufacturing process and increase the duration of its cycle to high extent.Gum Arabic is a neutral or slightly acidic salt of a complex polysaccharide composed of galactose, arabinose, rhamnose, glucuronic acid, 40-methyl glucuronic acid, calcium, magnesium and potassium, [12]. 
The objective of this study was to develop a composition of white soft cheese made from gum Arabic milk and to determine the effect of gum Arabic on chemical composition of the product.

\section{Preparation of cheese}

\section{Materials And Methods}

Fresh cow's milk was obtained from a dairy farm located at El Haj Yousif (Khartoum North). Rennet is a product of ChrHansen's (Denmark) salt of commercial grade was obtained from the local market.The cheeses were manufacture at College of Animal Production of Science and Technology, Khartoum North.Sudan University of Science and Technology.

\section{Analysis of milk}

Fresh raw cow's milk was analyzed using the lacto scan go (Aple Industries Services-La Roche surForon, France) the milk was prepared using fat separator apparatus (Alfa Laval) which separates the fat 3\%, $2.5 \%$ and $2 \%$ ) then used for preparation of the cheeses.

\section{Cheese manufacturing:}

The milk samples with the 3 levels of fat were pasteurized at $72{ }^{\circ} \mathrm{C}$ into double Jacket vats; the salt was added to the milk at the rate of $3 \%$. Rennet powder $(1 \mathrm{gm}) / 50 \mathrm{~kg}$ milk) were dissolved in a little amount of water and mixed with the milk, then stirred for five minutes and the mixture was left to stand for 2 hrs for coagulation. The curd was transferred into a wooden molds lined with cotton cloth, placed in a sloping table where it was left overnight for whey drainage. The prepared three types of cheese were cut into small cubes with stainless steel knife and then packed into sterile polyethylene bags and stored atrefrigerator temperature $\left(4^{\circ} \mathrm{C}\right)$ for 4 months ( from day zero - 120 days).

\section{Analysis of cheese}

Total solids, fat, crude protein and ash of the cheese samples are determined according to [13] and $\mathrm{pH}$ was determined according to [14]. Volatile fatty acids were determined according to [15].

\section{Statistical analysis}

The data were analyzed using [16] factorial randomized complete design and then the means were tasted and separated using least significant differences (LSD).

\section{Results}

Results in Table (1) showed that the protein content significantly $(\mathrm{P}<0.05)$ affect by levels of fat. The crude protein increased with increased levels of fat. The highest protein $(25.26 \pm 3.12 \%)$ was found in the cheese sample with $3 \%$ fat while the lowest $(23.15 \pm 2.51 \%)$ was recorded in the cheese samples with $2 \%$ of fat.The results illustrated that ash contents of the cheese samples were significantly $(\mathrm{P}<0.0 \%)$ different all treatments the highest ash $(6.22 \pm 0.65 \%)$ was in the cheese samples with $2.5 \%$ of fat while the lowest $(6.03 \pm 1.03 \%)$ was in the cheese with $3 \%$ of fat. The total solids of cheese samples increased significantly $(\mathrm{P}<0.05)$ with the levels of fat the highest total solids $(66.85 \pm 6.54 \%)$ was in the cheese samples with fat $2.5 \%$ while the lowest $(64.45 \pm 6.11 \%)$ was in the cheese samples with fat $3 \%$. The $\mathrm{pH}$ contents of the cheese sample increased significantly $(\mathrm{P}<0.05)$ by the levels of fat. The lowest $\mathrm{pH}(5.21 \pm 0.57 \%)$ was found in the cheese samples made from milk with $2 \%$ of fat, while the highest $(5.41 \pm 0.55 \%)$ in the cheese with $3 \%$ of fat. The highest volatile fatty acids $(2.62 \pm 0.5001 \mathrm{~N} \mathrm{NaOH} / 100$ gm cheese) was for the cheese samples with $2.5 \%$ in milk fat while the lowest $(2.31 \pm 0.320 .1 \mathrm{~N} \mathrm{NaOH} / 100 \mathrm{gm}$ cheese) was in cheese sample with $3 \%$ milk fat, Table (1).

Result in Table (1) showed that the fat contents of the cheese samples significantly $(\mathrm{P}<0.05)$ different in all treatments. The highest fat $(13.99 \pm 1.27 \%)$ was found in cheese samples with $2.5 \%$ milk fat, while the lowest one $(13.61 \pm 1.20 \%)$ was found in the cheese sample with $3 \%$ milk fat.Results in Table (2) illustrate the effect of different levels of fat on sensory characteristics of Sudanese low-fat cheese. Significant variation $(\mathrm{P}<$ $0.05)$ was found in the colour,flavour, texture and saltiness of the cheese samples. However, significant differences $(\mathrm{P}<0.05)$ were observed in colour of cheese samples, the highest colour scores $(5.90 \pm 1.23 \%)$ was recorded for the cheese samples with $3 \%$ milk fat, while the lowest on $(4.60 \pm 1.36 \%)$ was found in the cheese samples with $2 \%$ milk fat. The cheese samples with $3 \%$ milk fat recorded higher flavour and saltiness $(5.03 \pm 2.19 \%)$ and $4.47 \pm 1.29 \%)$, respectively, while the highest texture $(2.25 \pm 1.95 \%)$ was found in the cheese samples with $2.5 \%$ milk fat (Table 2).

\section{Effect of storage period on the chemical composition and sensory characteristics of white cheese}

Data in Table (3) showed that the protein contents of the cheese samples significantly $(\mathrm{P}<0.05)$ increased from $(21.82 \pm 3.49 \%)$ at day zero up to the $(25.47 \pm 1.77 \%)$ at day 120 of storage. The total solids 
contents of the cheese samples significantly $(\mathrm{P}<0.05)$ affected by the storage period (Table 3$)$ the highest total solids content $(70.59 \pm 5.85 \%)$ was recorded at day 120 , while the lowest one $(59.29 \pm 4.03 \%)$ was at day zero. The $\mathrm{pH}$ significantly $(\mathrm{P}<0.05)$ decreased from $(5.90 \pm 0.06 \%)$ at day zero up to $(4.44 \pm 0.06 \%)$ at day 120 (Table $3)$. The volatile fatty acids significantly $\mathrm{P}<0.05)$ decreased with the storage period. The highest volatile fatty acids $(2.62 \pm 0.2101 \mathrm{~N} \mathrm{NaOH} / 100 \mathrm{gm}$ cheese) were found at day 60 , while the lowest one $(2.34 \pm 0.340 .1 \mathrm{~N}$ $\mathrm{NaOH} / 100$ gm cheese) was recorded at day 120 of storage (Table 3 ).

The fat contents of the cheese samples was significantly $(\mathrm{P}<0.05)$ affected by the storage period (Table $3)$. The highest fat content $(14.39 \pm 1.48 \%)$ was found at day 90 , while the lowest one $(13.11 \pm 0.84 \%)$ was at day 60 . The ash contents significantly $(\mathrm{P}<0.05)$ affected by the storage period. The ash content increased from $5.60 \pm 0.89 \%$ ) at day zero up to $(6.12 \pm 0.40 \%$ ) at day 120 (Table 3). Results in Table (4) illustrated the sensory characteristics of the cheese samples as affected by the storage period. The results indicated that significant variations $(\mathrm{P}<0.05)$ were observed in colour, flavour, texture and saltiness. The best colour was for the cheese samples at day 60 and thereafter decreased in scores. The flavour and saltiness of the all cheese samples showed the same trends, while the texture decreased at day 60 and at day 90 then increased at day 120 .

\section{Discussion}

Effect of different levels of fat on chemical composition and sensory properties of Sudanese low-fat cheese The protein of the cheese samples was affected by the levels of fat Table (1) it was increased with the increased fat levels. The increased of protein could be attributed to absorption of moisture by curd, or could be attributed to contents of cheese samples. These results were in agreement with those reported by [17] who stated that the protein contents increased with the level of gum Arabic. Our results were in harmony with those reported by [18] who stated that the protein content of the cheese samples with $0.3 \%$ cumin oil was significantly $(\mathrm{P}<0.05)$ higher in comparison with the control cheese. Moreover, he added that crude protein contents increased significantly $(\mathrm{P}<0.05)$ as cumin oil concentration increase. Our results were in accordance with that found by [18] who stated that the protein content of cheese samples with cumin oil concentration was higher than that of the control cheese without cumin oil.Ash contents of the cheese samples were affected by the different levels of fat. It was increased with decreased levels of fat. The increased of ash content could be due to the absorption of salt by curd. Our findings were in line with those of [19] who revealed that the ash contents increased with the levels of cassava powder.The total solids of the cheese samples were affected by the levels of fat. It was increased with decreasing levels of fat (Table 1). The increase of total solids may be attributed to high moisture content in the cheese made from different levels of fat. These results were in harmony with those reported [1] who stated that the total solids increase in the cheese curd made from UFC led to an increase in moisture binding capacity in comparison with the cheese curd made from concentrated SM. Similar results were obtained by [20] who studied the effect of different levels of soybean milk on the chemical composition of the cheese made from buffalo milk.Moreover, [21] and [22] who reported the same results.

$\mathrm{PH}$ of the cheese samples decreased with the levels of fat. The decreased of $\mathrm{pH}$ could be due to the increase of moisture content or increased of the acidity; these results were in harmony with those of [23](Table 1). Fat content of the cheese samples was not significantly $(\mathrm{P}<0.05)$ affected by levels of fat.Fat levels were notsignificantly affectedthe fat content of the cheese samples (Table 1), these results were in agreement with those of [18]. The volatile fatty acids showed the same trends as fat contents (Table 1).Results in Table (2) illustrated that the cheese made from different levels of fat recorded the highest values for colour, flavour, texture and saltiness. The best for all parameters were recorded by the cheese made with $3 \%$ milk fat. This could be due to the good sources of milk used in this study. These results were in line with those reported by [18] who stated that the colour and texture of the cheese samples were not significantly $(\mathrm{P}<0.05)$ affected by cumin oil concentrations. However, the flavour and taste of the cheese were significantly $(\mathrm{P}<0.01)$ affected by cumin oil concentration. The highest flavour scores were recorded for the cheese samples with $0.3 \%$ cumin oil while the lowest one was for the control. Similar results were obtained [24] who stated that the colour and flavour of the white cheese was significantly $(\mathrm{P}<0.01)$ affected by milk source.Moreover, saltiness of the cheese was significantly $(\mathrm{P}<0.05)$ affected by milk source, while milk source was not significantly $(\mathrm{P}<0.05)$ affected the texture of white cheese (Table 2). The variation of colour and flavour of cheese may be attributed of the variation of fat of milk.

\section{Effect of storage period on chemical composition and sensory evaluation of Sudanese low-fat cheese}

Crude protein, total solids and ash contents of the cheese samples increased during the storage period (Table 3). This increase in total solids could be attributed to decrease in the moisture content as the results of lactic acid developments which are caused curd contraction [18]. Similar results were obtained by [25]; [26]. Moreover, increase in ash contents of cheese samples may be due to absorption of the moisture by the cheese during cold storage, these results were in line with those of [24]who obtained that the high ash contents of the cheese samples with the cumin oil concentration could be due to preservation effect of the cumin oil on the cheese components.Storage period showed significant variation in fat contents of cheese samples it was 
decreased at day 30 and at day 60, and then afterwards increased at day 90 and at day 120 of storage (Table 3). These results were in harmony with those of [27] who stated that the fat content of the lime cheese and grapefruit cheese samples stored in refrigerator were higher while the fat contents of the same cheese stored in whey at room temperature were low. Generally fat content of the lime cheese was higher than fat content of grapefruit cheese. The $\mathrm{pH}$ values of the cheese samples showed a decreasing trend from day zero up to the end of storage (Table 3) these results were in line with those of [28] who stated that the $\mathrm{pH}$ of the cheese showed a decreasing trend till the end of storage period. Out results were in accordance with those reported by [29] who obtained that the $\mathrm{pH}$ and acidity of treated samples did not differ significantly with the change of hydrocolloids, while $\mathrm{pH}$ decrease and acidity increase with storage. Volatile fatty acids showed the same trend of $\mathrm{pH}$ (Table 3). The storage period showed significant $(\mathrm{P}<$ 0.05 ) variations in all the sensory parameters (Table 4). The highest scores for flavour, texture and saltiness were at day zero, while the colour was found at day 60 of storage. The colour of cheese samples increased from day zero up to the end of storage, while the flavour, texture and saltiness decreased from the beginning till the end of the storage. The decrease might be due to the lipolytic and proteolytic action of microorganisms.

\section{Conclusion}

The study concluded that milk fat levels have significant effect on the chemical composition and sensory properties of low-fat cheese during storage period.

Table1: Effect of different levels of milk on chemical quality of Sudanese low-fat cheese.

\begin{tabular}{|l|l|l|l|l|l|l|}
\hline \multirow{2}{*}{ Fat level } & \multicolumn{6}{|l|}{ Chemical characteristic } \\
\cline { 2 - 7 } & Protein (\%) & Ash (\%) & Total solid (\%) & pH (\%) & VFA 0.IN NaOH/l00 g & Fat (\%) \\
\hline $3 \%$ & $25.26 \pm 3.12 \mathrm{a}$ & $6.03 \pm 1.03 \mathrm{c}$ & $64.45 \pm 6.11 \mathrm{c}$ & $5.41 \pm 0.55$ & $2.31 \pm 0.32$ & $13.61 \pm 1.20$ \\
\hline $2.5 \%$ & $23.91 \pm 2.46 \mathrm{~b}$ & $6.22 \pm 0.56 \mathrm{a}$ & $66.85 \pm 6.54 \mathrm{a}$ & $5.24 \pm 0.58$ & $2.62 \pm 0.50$ & $13.99 \pm 1.27$ \\
\hline $2 \%$ & $23.15 \pm 2.51 \mathrm{c}$ & $6.20 \pm 0.92 \mathrm{~b}$ & $66.77 \pm 6.02 \mathrm{~b}$ & $5.21 \pm 0.57$ & $2.46 \pm 0.32$ & $13.89 \pm 1.60$ \\
\hline LS & $* *$ & $*$ & $* *$ & NS & $* *$ & NS \\
\hline
\end{tabular}

Mean Values bearing different superscripts within rows are significantly $(\mathrm{P}<0.05)$.

L.S. = Levels of significance.

NS = Not significance.

Table 2: Effect different levels of fat on sensory characteristics of Sudanese low-fat cheese.

\begin{tabular}{|l|l|l|l|l|}
\hline \multirow{2}{*}{ Fat levels } & \multicolumn{4}{|l|}{ Sensory characteristics } \\
\cline { 2 - 5 } & Colour $\mathbf{( \% )}$ & Flavour $(\boldsymbol{\%})$ & Texture (\%) & Saltines (\%) \\
\hline $3 \%$ & $5.90 \pm 1.23 \mathrm{a}$ & $5.03 \pm 2.19$ & $4.13 \pm 2.12$ & $4.47 \pm 1.29$ \\
\hline $2.5 \%$ & $5.12 \pm 1.31 \mathrm{~b}$ & $4.22 \pm 1.49$ & $4.25 \pm 1.95$ & $4.36 \pm 1.22$ \\
\hline $2 \%$ & $4.60 \pm 1.36 \mathrm{c}$ & $3.97 \pm 1.59$ & $4.13 \pm 1.98$ & $3.90 \pm 1.06$ \\
\hline LS & $* *$ & $* *$ & NS & xx \\
\hline
\end{tabular}

Mean Values bearing different superscripts within rows are significantly $(\mathrm{P}<0.05)$.

L.S. = Levels of significance

NS = Not significance

Table 3: Effect of storage period on physicochemical characteristics of Sudanese low-fat cheese.

\begin{tabular}{|c|c|c|c|c|c|c|}
\hline \multirow{2}{*}{$\begin{array}{l}\text { Storage } \\
\text { period (days }\end{array}$} & \multicolumn{6}{|c|}{ Physicochemical characteristic } \\
\hline & Protein (\%) & Total (\%) & pH (\%) & $\begin{array}{lr}\text { VFA } & 0.1 \mathrm{~N} \\
\mathrm{NaOH} / \mathrm{l00} \mathrm{g} \\
\end{array}$ & Fat (\%) & Ash (\%) \\
\hline Zero & $21.82 \pm 3.49$ & $59.29 \pm 4.03$ & $5.90 \pm 0.06 \mathrm{a}$ & $2.50 \pm 0.67 \mathrm{~b}$ & $14.12 \pm 1.77$ & $5.60 \pm 0.89 \mathrm{~cd}$ \\
\hline 30 & $23.35 \pm 2.07$ & $67.20 \pm 5.09$ & $5.69 \pm 0.14 b$ & $2.49 \pm 0.38 \mathrm{c}$ & $13.81 \pm 1.25 \mathrm{~d}$ & $5.82 \pm 0.88 \mathrm{~d}$ \\
\hline 60 & $25.26 \pm 2.99$ & $69.28 \pm 4.61$ & $5.36 \pm 0.17 \mathrm{c}$ & $2.64 \pm 0.21 \mathrm{a}$ & $13.11 \pm 0.84 \mathrm{~cd}$ & $6.45 \pm 0.98 \mathrm{~b}$ \\
\hline 90 & $25.48 \pm 1.96$ & $66.07 \pm 4.95$ & $4.85 \pm 0.28 \mathrm{~d}$ & $2.46 \pm 0.29 \mathrm{~d}$ & $14.39 \pm 1.98 \mathrm{a}$ & $6.98 \pm 0.61 \mathrm{a}$ \\
\hline 120 & $25.47 \pm 1.77$ & $70.59 \pm 5.86$ & $4.44 \pm 0.14 \mathrm{~cd}$ & $2.34 \pm 0.34 \mathrm{~cd}$ & $14.03 \pm 1.29 \mathrm{c}$ & $6.12 \pm 0.40 \mathrm{c}$ \\
\hline LS & ** & *** & *** & ** & ** & *** \\
\hline
\end{tabular}

Mean Values bearing different superscripts within rows are significantly $(\mathrm{P}<0.05)$

L.S. = Levels of significance

Table 4: Effect of storage period on sensory characteristics of Sudanese low-fat cheese.

\begin{tabular}{|c|c|c|c|c|}
\hline \multirow{2}{*}{$\begin{array}{l}\text { Storage } \\
\text { period } \\
\text { (days) }\end{array}$} & \multicolumn{4}{|c|}{ Sensory characteristics } \\
\hline & $\begin{array}{l}\text { Colour } \\
(\%)\end{array}$ & $\begin{array}{l}\text { Flavour } \\
(\%)\end{array}$ & $\begin{array}{l}\text { Texture } \\
(\%)\end{array}$ & $\begin{array}{l}\text { Saltines } \\
(\%)\end{array}$ \\
\hline Zero & $4.47 \pm 1.43 \mathrm{~cd}$ & $6.47 \pm 1.43 \mathrm{a}$ & $6.54 \pm 1.40 \mathrm{a}$ & $5.51 \pm 1.32$ \\
\hline 30 & $4.93 \pm 1.45 \mathrm{~d}$ & $5.31 \pm 1.66 \mathrm{~b}$ & $4.05 \pm 1.25 \mathrm{c}$ & $4.09 \pm 0.99$ \\
\hline 60 & $5.97 \pm 1.00 \mathrm{a}$ & $4.61 \pm 1.33 \mathrm{c}$ & $2.83 \pm 1.30 \mathrm{~d}$ & $4.27 \pm 1.13$ \\
\hline 90 & $5.81 \pm 0.98 \mathrm{~b}$ & $3.89 \pm 1.02 \mathrm{~d}$ & $2.56 \pm 1.27 \mathrm{~cd}$ & $3.87 \pm 0.99$ \\
\hline 120 & $5.35 \pm 1.47 \mathrm{c}$ & $2.17 \pm 0.89 \mathrm{e}$ & $4.84 \pm 1.81 \mathrm{~b}$ & $3.62 \pm 0.98$ \\
\hline LS & *** & *** & *** & *** \\
\hline
\end{tabular}

Mean Values bearing different superscripts within rows are significantly $(\mathrm{P}<0.05)$.

L.S. = Levels of significance 


\section{References}

[1]. Lakovchenko, N.N. and Arseneva, T.P. (2016). Tapioca Maltodextrin in the production of soft unripened cheese. Acta. Sci. Pol. Technol. Aliment, 15(1): 27-56.

[2]. Krupa, H.; Jana A.; Tanu, H.; Patel, H.G. (2011). Synergy of dairy with non-dairy ingredients or product: A review. Afr. J. Food Sci., 5(16): 817-832.

[3]. Paul Kindstedt, 2005)

[4]. Ong, L.; Dagastine, R.R.; Kentish, S.E.; Gras, S.L. (2013). Microstructure and composition of full-fat cheddar cheese made with ultrafiltered milk retentive. Foods, 2(3): 310-331. 5

[5]. CFR (1974) U.S. code of Federal Regulations, 21: 101-1216.

[6]. Verbekenet al. (2003).

[7]. Paulson, B.M.; McMahon, D.J.; Oberg, C.J. (1998). Influence of sodium chloride on appearance, functionality and protein arrangement in non-fat Mozzarella cheese. J. Dairy Sci. 81(8): 2053-2064.

[8]. Drake, M.A.; Boylston, T.D.; Swanson, B.G. (1996). Fat mimetics in low-fat Cheddar cheese. J. Food Sci, 61(6): 1267-1271.

[9]. Kavas, G.; Oysun, G.; Kinik, O.; Usal, H. (2004). Effect of some fat replacers on chemical, physical and sensory attributes of lowfat white pickled cheese. Food chem., 88(3): 381-388.

[10]. Koca, N.; Metin, M. (2004). Textural, melting and sensory properties of low-fat fresh Kashar cheeses produced by using fat replacers.Int. Dairy J., 14 (4): 365-373.

[11]. Sipahioglu, O.; Alvarez, V.B.; Solanolopez, C. (1999). Structure, physicochemical and sensory properties of Feta cheese made with tapioca start and lecithin as fat mimetics. Int. Dairy J. 9(11): 783-789.

[12]. Youssef G. A., Youssef A. S., Talha S., El-Aassar S. A., 2014. Increased fructosyltransferase (levansucrase) production by optimizing culture condition from Pediococcusacidilacticicstrain in shaking batch cultures, Life Science Journal, 11(7), 33-47.

[13]. AOAC (2009). Official Methods of Ananlysis of the Association of Official Analytic Chemists, Benjamin Franklin Station, Washington, D.C.

[14]. Newlander, F.G.; A.L. Pirisi and L.M. Poste (1964). Method for determination biochemical values of milk products. J. Sci. Abstract, 4: 29-40.

[15]. Kosikowski F.V. and Ministry, V.V. (1997). Cheese and fermented milk foods, $3^{\text {rd }}$ Edition. F.V. Kosikowski and Associate, Brookton dale, NY.

[16]. SPSS (1998). SPSS version 11.0 and later run under windows, Mac and Linux.

[17]. Esmaiel, G.S.; Aspar, K.A.; Ali, M.; Hamid, T.; Abdol-Gaffar, O. and Hossein, A. (2012). The effect of arabic gum using on improving of texture and Rheological properties of Iranian low-fat white chees. American-Eurasian.J. Agric. and Environ. Sci. 8(5): 607-614

[18]. Hamid, O.I.A. (2014). Effect of cumin oil concentrations on chemical composition and sensory characteristics of Sudanese white cheese during ripening.Int. J. of current Microbiol.Applied Sci., 3(4): 961-968.

[19]. Dhoul, K.R.R. (2015). Effect of adding different levels of cassava powder (Manihot esculent) on physicochemical, microbiological and sensory characteristics during storage.Ph.D. Thesis, Sudan University of Science and Technology, Khartoum North, Sudan.

[20]. Biradar, G.S.; Gujar, S.K.; Dande, K.G. and Gaikwad, S.M. (2012). Studies on Physicochemical quality of paneer (Indian cheese) prepared from blends of soymilk and buffalo milk. J. Anim. Prod. Adv., 2(3): 142-145

[21]. Ronaldson, A.N.; Palatinik, D.R.; Nomi, Z. and Mercedes, E.C. (2014). Soft cheese-like product development enriched with soy protein concentrates. Food Science and Technologu, 55: 139-147.

[22]. Billal, A.M. (2000). Effect of partial substitution of soymilk on the chemical composition and sensory characteristics of white soft cheese.M.Sc. Thesis, University of Khartoum, Sudan.

[23]. Pinar, B.; Mustafa, M. (2011). Physicochemical and textural properties of imitation fresh kashar cheese prepared from casein, caseinates and soy protein. GIDA Journal, 36(1): 17-24

[24]. Hassanein, M.F.R.; Mahgoub, S.A. and El-Zaheir, K.M. (2013). Soft cheese supplemented with black cumin oil. Impact on food borne pathogens and quality during storage.Saudi Journal of Biological Sciences, Vol. 20 (in press).

[25]. Naser, A.A.I. and Hamid, O.I.A. (2016). Sensory characteristics of white soft cheese made from sunflower (Hellanthusannuus) seeds enzyme with different milk source. European J. of Pharm and Medical Res. 3(9): 105-108 .

[26]. Abdalla, M.O.; Elowni, O.A.O. and Kheir, S.A. (2011). Effect of storage period on quality of Sudanese white cheese (GibnaBayda) manufactured with Salanumdubium, U. of K. J. Agric. Sci., 19(2): 202-217.

[27]. Elhasseen, H.A.; Hamid, O.I.A. and Elwoni, O.A.O. (2014). Effect of lime and grapefruit extract as coagulants on chemical composition of Sudanese white soft cheese during storage. Inter. J. Adv. Res. Biol. Sci. 1(7): 123-130.

[28]. AbdelRazig, K.A. and Babiker, N.A.A. (2009). Chemical and microbiological properties of Sudanese white soft cheese made by direct acidification technique. Pakistan J. of Nut. 8(8): 1138-1143.

[29]. Gulzar, N.; Sameen, A.; Kan, M.I.; Huma,N.; Murtaza, M.A. and Rafig, S. (2015). Nutritional and functional properties of fruited cream cheese spread as influenced by hydrocolloids. J. of Food and Nutrition Res., 2015, vol. 3, No. 3, 191-195. 